\title{
Experiential Learning with Internal Audit Service Projects: Students' Perceptions
}

\author{
Narita Holmes, Carol Sullivan \\ University of Texas of the Permian Basin, Texas, USA
}

\begin{abstract}
Students are very familiar with their own universities and also are interested in improving their alma maters. The purpose of this research is to share insights about a project that can be used for both traditional Auditing courses and the Internal Auditing course. The project requires that students "audit” certain elements of the universities' non-confidential finances as well as perform operational and compliance techniques. The project creates synergy for experiential learning and improvement of university operations. Examples of educational issues that were improved with the operational audits are: (1) better information posted for office hours and class times; (2) better scripting for professors' and staff's voicemail messages; and (3) campus safety improvements. The students also seemed more enthusiastic about auditing and happy to contribute to the excellence of their university.
\end{abstract}

Keywords: experiential learning, educational performance, auditing

\section{Introduction}

In the new economy of higher education, both students and institutions are seeking activities that will add value not only to their educational experiences but also to the institutions. Experiential learning seems to create a win-win environment as students gain valuable work-based skills and organizations benefit from the work that the students do with their experiential learning projects. The purpose of this article is to present ideas and experiences related to internal auditing experiential learning projects. With effective experiential learning, the students will usually gain experience in order to more effectively perform their jobs when they complete their academic programs.

\section{Research Background and Literature Review}

Rose, Rose, and McKay (2007) studied the role of knowledge acquisition as it relates to auditing experience. They found that assessments of knowledge structures are valuable tools and that decision aids can impart expert-like knowledge structures to novice auditors. Westermann (2011) discussed the concerns that accounting firm partners have related to novice auditors requiring extensive "hand-holding" during their on-the-job learning. This article provides suggestions related to how to help novice auditors gain experience before they are actually paid for their services through experiential learning in their courses.

Virgil (2016) discussed the idea that professional education usually involves students gaining skills used in practice and the transmission of knowledge necessary to perform complex tasks in the legal profession. He

Narita Holmes, Lecturer, Accounting, University of Texas of the Permian Basin. Email: Holmes_N@utpb.edu.

Carol Sullivan, Associate Professor, Accounting, University of Texas of the Permian Basin. 
asserted that professional education also involves the formation of personal and professional ways of thinking, essentially a professional identity.

Kurpis and Hunter (2017) maintained that business schools can increase their competitiveness by offering students intercultural skills development opportunities integrated into the traditional curricula and offered an experiential learning activity. They found that the experiential learning activity led to a perceived increase in cultural knowledge, motivation, and confidence in the students' ability to communicate with people from other cultures - one of the AICPA core competencies.

D’Angelo, Macaleer, and Meier (2015) conducted a research in order to determine consulting-based projects and cooperative education, providing the same perceived learning. They found that computer-based projects have as much value as cooperative education in more than half of the applicable categories studied, and exceeded cooperative education in a couple of categories. The project proposed in this research article uses the conclusions found in the D'Angelo et al.'s study to give students an alternative to an internship or cooperative education in accounting.

Juergens (2012) examined the perceived utility of experiential learning in terms of how the academic programs affect the adaptability of trained skills and the behaviors to various work situations. Her study involved MBA students and found that the experiential learning course was both positively and significantly related to the transfer of skills. The conclusion of the study was that educators need to consider incorporation of experiential learning in their curriculum. Our research supports this finding in terms of offering a way in which the auditing classes' experiential learning will eventually help with the students' careers.

Huerta-Wong and Schoech (2010) tested the interaction of teaching techniques and learning environment by comparing virtual and face-to-face learning environments with respect to active listening concepts. They found that the face-to-face learning environments provided better results only when experiential learning techniques were used. Our current study uses listening concepts in a face-to-face environment to enhance the experiential learning environment.

Quinn and Shurville (2009) discussed the need to assess experiential learning as it has transition from just the enthusiasts to mainstream higher education with the new educational economics. They asserted that experiential learning must be both beneficial and manageable in order to succeed. The purpose of this current research is to provide insights in which experiential learning with auditing is both beneficial to students and the university as well as manageable for a semester project.

\section{Schools and Classes in Which the Project Has Been Implemented}

The authors have implemented this type of project at the following schools:

(1) University of St. Thomas. The President of the University asked Dr. Sullivan to develop an activity in which the students could help with the audit activities since there were very few internal auditors for the university;

(2) Texas Wesleyan University. Dr. Sullivan developed a forensic accounting version of the project for the students taking a fraud capstone project;

(3) University of Texas at Permian Basin. Professor Holmes used this project to teach students how to do the Quality Assurance Reports. The areas studies were the Physical Plant, Athletics, the JBS Leadership Institute, and two colleges in the University. The students enjoyed it immensely. 
The students seem to love this project. They gained a very different perspective of their university than the typical college students and they prided themselves in actively making improvements to their school by using the auditing function. The university participants seemed to really appreciate their efforts and that made them happy, too.

\section{Project Learning Objectives}

The learning objectives associated with this project are as follows:

(1) Understand and appreciate the role of auditing in terms of making operational improvements with organizations;

(2) Be able to identify and assess risk based on observations and inquiries;

(3) Develop an audit plan and implement that plan;

(4) Create a report and a list of recommendations based on the audit findings;

(5) Communicate the results and recommendations to high-level administrators;

(6) Be able to work in audit teams and assess performance through both reflection and evaluation of others on the team;

(7) Provide value-added information to university administrators.

\section{Activities Involved with the Project}

The projects vary from semester to semester, but the following as some typical audit project activities:

(1) Complete campus walk-through both during the day and at night to get a better understanding of possible issues that can arise. Night tours are helpful in determining whether lights are operating properly, risk assessment of unauthorized people wandering the campus when there are less classes and personnel in place;

(2) Develop an audit plan to check on the operational activities of the professors. Using phone lists, call the professors during office hours to see if they answer. Also, call the numbers at night to see how the voicemail messages sound. Check their offices (based on information provided in syllabi or the university website) to see if their offices meet professional standards as well as check to see if the professors are making their office hours. Check the professors' classrooms when they are supposed to be teaching to make sure that they are actually meeting their classes properly. Check the professors' syllabi to make sure that they meet the university standards for information included as well as information that should not be found in a syllabus is excluded;

(3) Check the university emergency call phones to make sure that they actually work and check whether the university's emergency number is operational on a regular basis;

(4) Perform risk assessment when deviations occur and make recommendations;

(5) Communicate findings and recommendations to high-level administrators, trustees, or regents in the same way that auditors would present findings and recommendations to the audit committee of a company's board of directors.

\section{Results of the Projects}

While many items are confidential in nature, the following items are the more public issues discovered with the projects and corrective actions taken: 
(1) Critical night lights burned out throughout the campus... bulbs were replaced and a systematic approach to checking night lights was developed by the physical plant department (where the employees usually work during the day);

(2) Classrooms with high-dollar equipment were left open for extended periods of time without any classes... professors were instructed to lock the classrooms and security personnel systematically checked for open classrooms at strategic hours of the day/night;

(3) Many unauthorized people on the campus... student IDs required to be carried on campus and employee IDs were actually worn;

(4) Equipment costing more than $\$ 500$ was not inventoried/identified in any way... a systematic approach with respect to purchase requisitions, orders, receiving, and payments was developed; annual inventory of items was also required;

(5) All sorts of deviations taking place with respect to voicemail messages... a script was developed to teach professors to identify their name, their university, and their department as part of the voicemail message to be heard by students, etc.;

(6) All sorts of deviations taking place with respect to syllabi formats and information... a template was developed and all syllabi was required to be approved by the Deans' offices before they were published and distributed to the students;

(7) Some deviations taking place with respect to professors meeting their classes and being available for office hours... systematic checks were developed and implemented by student workers/administrators in the Deans' offices.

Unfortunately, administrators do not implement all of the recommendations made by the students at times. Here are two examples of what happened when recommendations were ignored:

(1) Driver Background Checks for the University Vans... crash by a person with a deficient driving record; there is now a very elaborate driver background check and a requirement that a National Defensive Driving course must also be completed before a person is placed on the university's "approved driver" list;

(2) Timely Deposits of Library Fines... either a staged robbery by a library insider or a real robbery in the library with a loss of $\$ 300$; a deposit is now required when the fines exceed $\$ 50$.

\section{AICPA Core Competencies Address with the Experiential Learning Projects}

With changes in the accounting programs, the American Institute of Certified Public Accountants (AICPA) has recommended several core competencies related to functional, personal, and the broad business perspective skills in students' academic experiences.

Students improve with the following functional competencies when completing the project:

(1) Decision modeling - since every project is different, students have to make decisions related to what they deem operationally important to check as well as what to do about deviations in their audit experiences;

(2) Risk analysis - students have to assess risk when making judgment about what to check and determine the risk increase when deviations take place;

(3) Measurement - students have to count the population instances that are being checked as well as make statistical inferences when deviations take place;

(4) Reporting - students make a report of their entire audit process; 
(5) Research - students will research "best practices" found at universities and also review the university's financial statements when possible and Clery Act stats;

(6) Leverage technology to develop and enhance functional competencies - students are usually testing the technology being used at the university and that helps them enhance their own functional competencies through technology.

Students made improvements with the following personal competencies as they completed the project:

(1) Professional demeanor - students have to develop a professional demeanor as they make their observations and inquiries. Professorial supervision also helps with this area;

(2) Problem-solving and decision-making - students have to solve problem and make decisions in order to conduct their risk assessments, observations, and inquiries. They also use these competencies when encountering deviations;

(3) Interaction - students will have to interact with faculty/staff/administrators with the project and will have to stay productive in order to complete it;

(4) Leadership - students work in teams so that leadership skills can be developed and the leadership roles usually change throughout the processes;

(5) Communication - students communicate their findings and recommendations to high-level administrators or regents or trustees;

(6) Project management - students develop an audit plan and an audit schedule in order to properly manage the project;

(7) Leverage technology to develop and enhance personal competencies - students develop a PPT presentation in order to communicate their findings and recommendations.

Students gained the following broad business perspectives competencies by completing the projects:

(1) Strategic/critical thinking - students go from assessing the university from just a student perspective to thinking about long-term strategic effects of campus safety problems and other deviations that may take place with the audit. They need to share a "big picture" perspective when making their presentations and not get stuck on minute details;

(2) Industry/sector perspective - after conducting the audit, the students have a much better understanding of higher education as an industry;

(3) International/global perspective - since many of the students are international, a comparison/contrast can be made related to universities in other countries;

(4) Legal/regulatory perspective - Students can gain perspectives related to the Clery Act reporting requirements as well as Family Educational Rights and Privacy Act (FERPA) issues;

(5) Marketing/client focus - students are in the unique position of having their own alma mater as their client.

\section{Students' Perceptions}

While most accounting professors would probably think that experiential learning with the auditing projects is a good idea, it is important to find out what the students think of the projects. The questionnaire asked three basic questions related to the strengths, weaknesses, and opportunities for improvement. The results of the students' perceptions are as follows (see Table 1). 
Table 1

Results of the Student Perceptions' Questionnaire

\begin{tabular}{|c|c|}
\hline Questions & Answers \\
\hline \multirow{18}{*}{ 1. What, to you, was the most valuable aspect of the project? } & $\begin{array}{l}\text { The whole thing was valuable. I think all students benefit } \\
\text { from something hand-on. I appreciated doing an actual } \\
\text { audit and not a made-up project. }\end{array}$ \\
\hline & $\begin{array}{l}\text { The whole process. Being able to actually do it not just } \\
\text { read about in the textbook. }\end{array}$ \\
\hline & Verifying all the pieces laid out together. \\
\hline & The hands-on experience. \\
\hline & The learning process was the most valuable aspect. \\
\hline & $\begin{array}{l}\text { Learning how the process works and what can be } \\
\text { discovered by poor or good choices in sampling and } \\
\text { gathering information from several different sources. }\end{array}$ \\
\hline & Being able to audit an actual audit. \\
\hline & $\begin{array}{l}\text { Working as a team, Bethany did an excellent job as did } \\
\text { Meagan. }\end{array}$ \\
\hline & $\begin{array}{l}\text { The actual hands-on aspect really increased learning the } \\
\text { material. Also, being able to perform the initial interview } \\
\text { with the internal control questionnaire really brings to } \\
\text { light the human side of performing an audit. Watching } \\
\text { reactions to questions and deciphering those reactions } \\
\text { brings the classroom details to light. }\end{array}$ \\
\hline & The fact that it was real. What we did really mattered. \\
\hline & $\begin{array}{l}\text { Dealing with people in a real-life situation, I think students } \\
\text { get disillusioned when they come to work and all the } \\
\text { information you need is not readily available in a word } \\
\text { problem. }\end{array}$ \\
\hline & $\begin{array}{l}\text { It showed some of the aspects of being an auditor and } \\
\text { working on an accounting team in a business setting. }\end{array}$ \\
\hline & $\begin{array}{l}\text { Actually, seeing how the audit works in real life helped all } \\
\text { the theories in the book make more sense. I was irritated } \\
\text { with the book about how much they went on and on about } \\
\text { planning, but then when we got started on the project and } \\
\text { wasted so much time just spinning our wheels, all that } \\
\text { planning made more sense. }\end{array}$ \\
\hline & $\begin{array}{l}\text { Starting to develop an audit mentality that can be carried } \\
\text { over to working to avoid problems that could come up in } \\
\text { audits. }\end{array}$ \\
\hline & $\begin{array}{l}\text { Getting some actual work experience that was totally new } \\
\text { to me. }\end{array}$ \\
\hline & $\begin{array}{l}\text { When we finished our project, I understood exactly how } \\
\text { everything came together. }\end{array}$ \\
\hline & $\begin{array}{l}\text { This project was very valuable in obtaining an insight on } \\
\text { how audits actually work. Even for students that may not } \\
\text { be interested in becoming auditors, it will help them } \\
\text { understand what auditors are looking for and why } \\
\text { compliance with accounting and internal control } \\
\text { regulations are so critical in all businesses. There are few } \\
\text { classes that provide such "real world" experience, and it is } \\
\text { a very valuable exercise to produce a well-rounded } \\
\text { accountant and business person. }\end{array}$ \\
\hline & $\begin{array}{l}\text { Most valuable aspect was seeing the steps from start to } \\
\text { finish. I would not have the same understanding if I would } \\
\text { have just read a book. }\end{array}$ \\
\hline
\end{tabular}


(Table 1 continued)

\begin{tabular}{|c|c|}
\hline Questions & Answers \\
\hline \multirow{20}{*}{$\begin{array}{l}\text { 2. What were the most difficult problems you encountered in } \\
\text { completing the audit project? }\end{array}$} & Obtaining information from the department. \\
\hline & $\begin{array}{l}\text { Getting the information and understanding the numbering } \\
\text { system. }\end{array}$ \\
\hline & Getting staff to return phone calls. \\
\hline & Cooperation among our group. \\
\hline & $\begin{array}{l}\text { More documents that support the transactions and other } \\
\text { information. }\end{array}$ \\
\hline & $\begin{array}{l}\text { The most difficult problem was coordinating team } \\
\text { members' schedules so that the entire team was working } \\
\text { effectively. This caused delays in the completion } \\
\text { of the audit. The actual audit process was not too difficult. }\end{array}$ \\
\hline & $\begin{array}{l}\text { Obtaining complete information from the department and } \\
\text { knowing what to look for. }\end{array}$ \\
\hline & $\begin{array}{l}\text { At beginning, I was confused to how to read those account } \\
\text { information and where to start. }\end{array}$ \\
\hline & $\begin{array}{l}\text { The most difficult problem would have been trying to } \\
\text { understand how the accounting process works for the } \\
\text { university; however, learning this throughout the process } \\
\text { was an excellent learning tool. }\end{array}$ \\
\hline & Just figuring out exactly what to do. \\
\hline & $\begin{array}{l}\text { The only problem that I saw was in the delay that the } \\
\text { department had in responding to the service request. I } \\
\text { didn't expect them to have the request ready the next day, } \\
\text { but it would help to be notified that at least the request was } \\
\text { received. }\end{array}$ \\
\hline & $\begin{array}{l}\text { Knowing exactly what steps we needed to take to actually } \\
\text { perform the audit. }\end{array}$ \\
\hline & The difficulty in getting partners together at the same time. \\
\hline & $\begin{array}{l}\text { It was too much to take in at first, but things smooth out at } \\
\text { the end. }\end{array}$ \\
\hline & Understanding some of the office procedures. \\
\hline & $\begin{array}{l}\text { The problems I encountered were going through } \\
\text { documentation and being confident that I had found } \\
\text { sufficient documentation. }\end{array}$ \\
\hline & Finding the correct papers to answer the questions. \\
\hline & $\begin{array}{l}\text { It felt overwhelming when we first started, the papers in } \\
\text { the box we had never seen before. It was hard looking for } \\
\text { what we needed without actually knowing how it looked. }\end{array}$ \\
\hline & $\begin{array}{l}\text { My biggest obstacle was the general disorganization of our } \\
\text { department. }\end{array}$ \\
\hline & Our director was uncooperative and rude sometimes. \\
\hline \multirow{4}{*}{ 3. Do you have any other suggestions for improvement of the course? } & $\begin{array}{l}\text { I think the time required for this project should be } \\
\text { emphasized. This is especially true for the managers. I } \\
\text { would also recommend detailed, face-to-face experiences. }\end{array}$ \\
\hline & $\begin{array}{l}\text { Introducing the audit project earlier in the semester and } \\
\text { getting all the fieldwork two months before the audit } \\
\text { begins to give each team enough time to work } \quad \text { on it. }\end{array}$ \\
\hline & $\begin{array}{l}\text { I would have liked to have more lecture time dedicated to } \\
\text { the current process in the audit project. For example, } \\
\text { during the field work stage explain some of the } \\
\text { documentation and tactics used in actual practice. }\end{array}$ \\
\hline & $\begin{array}{l}\text { One of the most valuable classes in accounting I have } \\
\text { taken. }\end{array}$ \\
\hline
\end{tabular}


(Table 1 continued)

\begin{tabular}{|c|c|}
\hline Questions & Answers \\
\hline \multirow{6}{*}{ 3. Do you have any other suggestions for improvement of the course? } & $\begin{array}{l}\text { Maybe lessening the number of departments to be audited } \\
\text { during the semester to allow for larger teams. This may } \\
\text { allow team members more exposure to other areas of the } \\
\text { audit. For instance, I was only responsible for the } \\
\text { expenditures portion and, as a result, I didn't get to } \\
\text { experience any of the other sections. Maybe by increasing } \\
\text { the number of team members, a little time can be spent on } \\
\text { more than one section by each team member. }\end{array}$ \\
\hline & $\begin{array}{l}\text { I enjoyed the course and wish more classes were set up the } \\
\text { same way. That said, the chapter was very fast paced and I } \\
\text { found it overwhelming at times. }\end{array}$ \\
\hline & Just more time on the audit project in class. \\
\hline & $\begin{array}{l}\text { I think having checklists for the files that should be turned } \\
\text { at each due date would be helpful. Also, maybe a } \\
\text { simplified audit program specifically for the class audit } \\
\text { would help, too. I felt a little lost trying to organize the } \\
\text { papers to turn in and make sure we didn't miss anything. }\end{array}$ \\
\hline & $\begin{array}{l}\text { Ms. Holmes is a great instructor for this course. She is a } \\
\text { very interesting person and has a lot of life experience in } \\
\text { the field and she is so knowledgeable about what she does. } \\
\text { The course was also very interesting but there is so much } \\
\text { to it that it is a bit overwhelming and sometimes causes to } \\
\text { lose focus. I really don't know that there is much you can } \\
\text { do to change that but that was the hardest part of the } \\
\text { course. }\end{array}$ \\
\hline & $\begin{array}{l}\text { No improvements. I just want to tell you I really enjoyed } \\
\text { your class. It is an interesting field. I'm speaking for } \\
\text { myself, but I really enjoyed your class. The examples from } \\
\text { personal experience always help. I can't remember them } \\
\text { in a test, but I do think about them when I'm working. } \\
\text { Thanks for a wonderful semester. }\end{array}$ \\
\hline
\end{tabular}

\section{Concluding Remarks}

This study offers ideas and experiences related to students conducting internal audit projects as part of their experiential learning in auditing courses. Students are very familiar with their own universities and also are interested in improving their alma maters. The project requires that students "audit" certain elements of the universities' non-confidential finances as well as perform operational and compliance techniques. The project creates synergy for experiential learning and improvement of university operations. After completing the projects, the students also seemed more enthusiastic about auditing and happy to contribute to the excellence of their university. Students seemed to like the project overall and seemed to learn the practical aspects of auditing, both good and bad, with this experience.

\section{References}

D’Angelo, D., Macaleer, A., \& Meier, K. (2015). Consulting-based action learning as an experiential learning alternative to traditional co-operative education. Academy of Business Research Journal, 3, 53-60.

Huerta-Wong, J. E., \& Schoech, R. (2010). Experiential learning and learning environments: The case of active listening skills. Journal of Social Work Education, 46(1), 85-101.

Juergens, S. (2012). Experiential learning: How the utility of experiential learning within a MBA course enables transfer of learning. Proquest Dissertation Publishing.

Kurpis, L. H., \& Hunter, J. (2017). Developing students' cultural intelligence through an experiential learning activity. Journal of Marketing Education, 39(1), 30-46. 
Quinn, D., \& Shurville, S. (2009). From little things big things grow: Scaling-up assessment of experiential learning. Campus-wide Information Systems, 26(4), 329-344.

Rose, J., Rose, A., \& McKay, B. (2007). Measurement of knowledge structures acquired through instruction, experience, and decision aid use. International Journal of Accounting Information Systems, 8(2), 117-137.

Virgil, S. M. (2016). The role of experiential learning on a law student's sense of professional identity. Wake Forest Law Review, 51(2), 325-338.

Westermann, K. (2011). Learning the "craft of auditing": Applications of the cognitive apprenticeship framework. Proquest Dissertation Publishing, Bentley University, 3507845. 